\title{
Rock-phosphate solubilising bacteria and their effect on soybean (Glycine max) growth under pot grown conditions
}

\author{
Fankem Henri $^{1,}$,, Nguesseu Njanjouo Ghislain ${ }^{1}$, Ngo Nkot Laurette ${ }^{1}$, \\ Tchuisseu Tchakounte Gylaine Vanessa ${ }^{1}$, Nwaga Dieudonné2, Etoa François-Xavier ${ }^{2}$ \\ ${ }^{1}$ Department of Plant Biology, Faculty of Science, University of Douala, Douala, Cameroon \\ ${ }^{2}$ Department of Microbiology, Faculty of Science, University of Yaoundé I, Yaoundé, Cameroon \\ Email address: \\ fankemhenri@yahoo.fr (F. Henri)
}

To cite this article:

Fankem Henri, Nguesseu Njanjouo Ghislain, Ngo Nkot Laurette, Tchuisseu Tchakounte Gylaine Vanessa, Nwaga Dieudonné, Etoa François-Xavier. Rock-Phosphate Solubilising Bacteria and their Effect on Soybean (Glycine max) Growth under Pot Grown Conditions. American Journal of Agriculture and Forestry. Vol. 2, No. 4, 2014, pp. 100-109. doi: 10.11648/j.ajaf.20140204.11

\begin{abstract}
The modern agriculture is dependent on phosphorus (P) derived from phosphate rock. However, the direct application of low-grade rock phosphate as a $\mathrm{P}$ source in soils need an addition of inoculums of phosphate solubilising microorganisms to improve the rock phosphate efficiency as a phosphorus source. Phosphate solubilising bacteria (PSB) were screened for their phosphate solubilising ability on plates and in liquid cultures supplemented with Malian, Moroccan or Mexican rock phosphates. They were subsequently tested on soybean grown in pots filled with non sterile soil amended with Moroccan rock phosphate for their aptitude in promoting soybean growth. The activity of the different strains on plates indicates Panthoea sp. and Bacillus sp. as the most efficient strains able to show halo zone on plates supplemented all different rock phosphates, with a solubilisation index (SI) of 3.65, 4.10 and 5.42 (Panthoea sp.) and 2.93, 3.13 and 2.13 (Bacillus sp.) respectively for Malian, Moroccan and Mexican rock phosphates. Panthoea sp. remains the strains showing the highest concentration of the solved P with all rock phosphates: 1038.25, 996.67 and $1207.87 \mu \mathrm{gP} / \mathrm{g}$ for Malian, Moroccan and Mexican rock phosphates respectively. It is followed by Klebsiella sp. (862.57, 615.19 and $426.29 \mu \mathrm{gP} / \mathrm{g}$ respectively) and Bacillus sp. (810.86, 270.92 and $180.95 \mu \mathrm{gP} / \mathrm{g}$ ). In general, Panthoea sp. and Bacillus sp. better contribute to the soybean growth with the effect of $35 \%$ and $34 \%$ respectively compare to non inoculated control supplied with non soluble Moroccan rock phosphate. The activity of Klebsiella sp. (13\%) that is low in general seems to be stimulated when associated with the two other strains (33\%). This suggests that the use of rock phosphate combined with the co-inoculation with those strains would ensure soybean production in economically profitable and environmentally friendly conditions.
\end{abstract}

Keywords: Phosphate Solubilising Bacteria, Rock Phosphate, Rock Phosphate Solubilisation, Soybean Growth

\section{Introduction}

After nitrogen, phosphorus (P) is an essential plant nutrient whose deficiency restricts crop yields severely [1]. It plays an important role in virtually all major metabolic processes in plant including photosynthesis, energy transfer, signal transduction, macromolecular biosynthesis and respiration [2]. Tropical and sub tropical soils are predominantly acidic, and often extremely phosphorus deficient [3] with high phosphorus fixation capacities. Phosphorus is added to soil in the form of phosphatic fertilizers, part of which is utilized by plants and the remainder converted into insoluble fixed forms. It is well documented that major fractions of soil phosphorus are usually present in the forms which are unavailable to plant [4]. This leads to the need of frequent application of phosphate fertilizers, but its use on a regular basis has become a costly affair and environmentally undesirable [5]. Therefore, the necessity to develop economical and ecofriendly technologies is steadily increasing $[6,7,8]$. Natural rock phosphates have been recognised as a valuable alternative for $\mathrm{P}$ fertilisers, the modern agriculture being dependent on phosphorus derived from phosphate rock [9]. However, the direct application of low-grade rock 
phosphate as a $\mathrm{P}$ source in neutral and alkaline soils was of little importance $[10,11]$, but addition of an inoculums of phosphate solubilising microorganisms to soil has also been found to improve the rock phosphate efficiency as a phosphorus source [12]. Many soil microorganisms, including bacteria and fungi, are able to mobilize phosphorus from sparingly soluble rock phosphates, and they have an enormous potential in providing soil phosphates for plant growth [13, 14]. These organisms are ubiquitous but vary in density and mineral/rock phosphate solubilising ability from soil to soil or from one production system to another. They are generally isolated from rhizosphere and nonrhizosphere soils, rhizoplane, phyllosphere, and rock $\mathrm{P}$ deposit area soil and even from stressed soils using serial plate dilution method or by enrichment culture technique [4]. Once a potential isolate is identified, it must be further tested for direct contribution to $\mathrm{P}$ plant nutrition and not necessarily to general growth promotion, as commonly done because promotion of growth, even by phosphate solubilising bacteria (PSB), can be the outcome of other mechanisms [15] and ability to solubilise $\mathrm{P}$ is not necessarily correlated with the ability to promote plant growth [16]. Therefore, this study is conducted to characterize three bacterial strains in solubilising rock phosphates as well as their impact in promoting soybean growth under pot grown conditions.

\section{Materials and Methods}

\subsection{Microorganisms}

All the strains used in this study are from the strain bank of the Laboratory of Biotechnology, Faculty of Science, University of Douala. Strains were isolated from soil collected in three agro ecological zones of Cameroon; Klebsiella sp. in zone I, Panthoea sp. in zone II, and Bacillus sp. in zone IV. They have been previously screened for their ability in solubilising sparingly soluble phosphates including $\mathrm{Ca}_{3}\left(\mathrm{PO}_{4}\right)_{2}, \mathrm{AlPO}_{4}, \quad \mathrm{FePO}_{4}$ and sodium-phytate, and would be recognized as inorganic/organic phosphate solubilisers.

\subsection{Rock Phosphates}

Rock phosphates of different origins and analyzed for their chemical contents (Table 1) were used: the Tilemsi rock phosphate from Mali, Gafsa rock phosphate from Mexico and Moroccan rock phosphate.

To get rid of their soluble fractions, the different rock phosphates were washed 4 times with warm water following the cycle: 1 hour - 24 hours -1 hour - 24 hours. They were then dried at $60{ }^{\circ} \mathrm{C}$ until complete evaporation of water and homogenized before use.

Table 1. Mineralogical composition of the different rock phosphates used (Magallón-Servín, unpublished).

\begin{tabular}{llllllllllll}
\hline \multirow{2}{*}{ Origin rock $\mathbf{P}$} & \multicolumn{3}{l}{ Mineral elements (\%) } & \multicolumn{1}{l}{$\mathbf{m}$} & \multicolumn{1}{c}{$\mathbf{m g} / \mathbf{k g}$} \\
\cline { 2 - 12 } & Total $\mathbf{P}_{\mathbf{2}} \mathbf{O}_{\mathbf{5}}$ & Available $\mathbf{P}$ & $\mathbf{K}$ & $\mathbf{C a}$ & $\mathbf{M g}$ & $\mathbf{N a}$ & $\mathbf{F e}$ & $\mathbf{A l}$ & $\mathbf{M n}$ & $\mathbf{Z n}$ & $\mathbf{C u}$ \\
\hline Mali & 30 & 12.98 & 0.056 & 28.19 & 0.131 & 0.232 & 3.844 & 0.80 & 8360 & 87 & 51 \\
Mexico & 28 & 8.87 & 0.219 & 25.94 & 0.222 & 0.358 & 0.442 & 0.58 & 788 & 103 & 18 \\
Morocco & 13 & 9.33 & 0.093 & 28.83 & 1.93 & 0.552 & 0.267 & 0.42 & 96 & 219 & 38 \\
\hline
\end{tabular}

\subsection{Preparation and Evaluation of the Concentration of the Inoculums}

To prepare inoculums from each bacterial strain, pure bacterial colony was individually suspended into $50 \mathrm{ml}$ Nutrient Broth (NB) (5 g Peptone, 1 g Beef extract, 2 g Yeast extract, $5 \mathrm{~g}$ Sodium chloride, $1000 \mathrm{ml}$ Distilled water, $\mathrm{pH}$ 7.0) and incubated at $28{ }^{\circ} \mathrm{C}, 150 \mathrm{rpm}$, for 3 days. Cultures were then spin at $10.000 \mathrm{~g}, 10$ minutes at $4{ }^{\circ} \mathrm{C}$, followed by three times washing with $0.85 \%$ sterile $\mathrm{NaCl}$ at the same conditions. Bacterial cells were resuspended into $0.85 \%$ sterile $\mathrm{NaCl}$ and the OD adjusted to 0.2 at $620 \mathrm{~nm}$. To assess the number of bacterial cells per milliliter, $1 \mathrm{~mL}$ of bacterial suspension, OD 0.2 was serial diluted until $10^{-7}$. $200 \mu \mathrm{L}$ of dilutions $10^{-7}, 10^{-6}, 10^{-5}$ were used to inoculate Nutrient Agar (NA) (5 g Peptone, 1 g Beef extract, 2 g Yeast extract, $5 \mathrm{~g}$ Sodium chloride, $15 \mathrm{~g}$ Agar, $1000 \mathrm{ml}$ Distilled water, $\mathrm{pH}$ 7.0) plates in duplicate. After incubation at $28{ }^{\circ} \mathrm{C}$, for 4 days, bacterial colonies were counted and the number of Colony Forming Unit (CFU) per $\mathrm{mL}$ recorded. Counting colonies allowed the determination of the concentration of the inoculum evaluated to $1-1.7 \times 10^{9}$ $\mathrm{CFU} / \mathrm{mL}$. Consortia of strains were freshly prepared by mixing equal volumes of the different strain suspensions.

\subsection{Bacterial Rock Phosphate Solubilising Capacity on Agar Plate}

The characterisation of strains for their rock phosphate solubilising ability was assessed on plates filled with the National Botanical Research Institute's Phosphate growth medium (NBRIP) [17] with some modifications and containing per litre of distilled water: $20 \mathrm{~g}$ glucose, $5 \mathrm{~g}$ $\mathrm{MgCl}_{2} \cdot 6 \mathrm{H}_{2} \mathrm{O}, 0.25 \mathrm{~g} \mathrm{MgSO}_{4} \cdot 7 \mathrm{H}_{2} \mathrm{O}, 0.2 \mathrm{~g} \mathrm{KCl}, 0.1 \mathrm{~g}$ $\left(\mathrm{NH}_{4}\right)_{2} \mathrm{SO}_{4}$ and one rock phosphate type at $5 \mathrm{~g} . \mathrm{L}^{-1}$ (Malian RP, Moroccan RP or Mexican RP), plus $0.5 \%$ bromocresol green [18], $\mathrm{pH}$ 7.5. A stock solution of $0.5 \%$ dye was prepared by dissolving a corresponding weight of bromocresol green into $70 \%$ ethanol and the final $\mathrm{pH}$ adjusted to 6.5 with $1 \mathrm{M} \mathrm{KOH}$. Five microliters of each bacterial suspension obtained as described above were transferred onto a single point of compartmented Petri dish. The plates were sealed and incubated at $28^{\circ} \mathrm{C}$ for 5 days and the phosphate solubilisation recorded through the halo/yellow zone surrounding the bacterial colony. The index of solubilisation (IS) as defined by Qureshi et al. [19] 
was used as an indicator for the isolate efficiency: IS = (Colony diameter + diameter of halo zone) / Colony diameter.

\subsection{Quantitative Estimation of Phosphate Solubilisation by Bacteria in Liquid Media}

Bacteria were tested in liquid media to assess their capability in releasing phosphorus from insoluble rock phosphate sources. $50 \mathrm{ml}$ NBRIP medium were distributed into $250 \mathrm{~mL}$ Erlenmeyer flasks, individual rock phosphate types (Malian RP, Moroccan RP or Mexican RP) were added to the medium at the concentration of $5 \mathrm{~g} . \mathrm{L}^{-1}$ and the $\mathrm{pH}$ adjusted to 7.5. After sterilization and cooling, $200 \mu \mathrm{l}$ bacterial suspensions of $1-1.7 \times 10^{9} \mathrm{CFU} / \mathrm{mL}$ were used to inoculate flasks containing the different rock phosphates. Each treatment was performed in triplicate and noninoculated flasks supplemented with the different rock phosphates supplied with $200 \mu \mathrm{l} 0.85 \%$ sterile $\mathrm{NaCl}$ served as controls. Incubation was made at $28{ }^{\circ} \mathrm{C}, 150 \mathrm{rpm}$ for 7 days. At end of the incubation time and in all cases, the cultures were transferred into sterile falcon tubes, centrifuged at $10.000 \mathrm{~g}$ for 10 minutes at $4{ }^{\circ} \mathrm{C}$, a part of the supernatant taken for $\mathrm{pH}$ measurement and another part for $\mathrm{P}$ determination following the method described by Murphy $\&$ Riley [20].

\subsection{Pot Experiment}

The pot experiment was conducted to assess the effect of a single strain or consortia of strains on soybean (Glycine max) growth. The experiment was conducted in 3 liters pots containing homogenized non-sterile soil with the following characteristics: $\mathrm{pH} \mathrm{H}_{2} \mathrm{O}, 5.5$; $\mathrm{pH} \mathrm{KCl}, 4.4$; nitrogen, $0.06 \%$; available phosphorus, $7.54 \mathrm{ppm}$; organic matter, $0.59 \%$; organic carbon, $0.34 \%$; iron, $1.75 \mathrm{ppm}$; aluminium, 0.29 méq $/ \mathrm{g}$; calcium, $1.04 \mathrm{méq} / \mathrm{g}$; magnesium, $1.60 \mathrm{méq} / \mathrm{g}$; potassium, 0,.15 méq/g; sodium, 0.07 méq $/ \mathrm{g}$. The experiment consisted of 12 treatments including 10 microbial treatments and two controls. The microbial treatments consisted of three single inoculations respectively labeled A (Panthoea sp.), B (Klebsiella sp.), C (Bacillus sp.) and two consortia AC (Panthoea sp. + Bacillus sp.) and ABC (Panthoea sp. + Klebsiella sp. + Bacillus sp.). All the pots, except the positive control were amended with Moroccan rock phosphate at the rate of 80 $\mathrm{kg} \cdot \mathrm{ha}^{-1}\left(0.3625 \mathrm{~g}\right.$ for $\left.0.8836 \mathrm{dm}^{3}\right)$ to increase the amount of phosphorus in soil. All the pots were equally supplied with potassium at the rate of $80 \mathrm{~kg} \mathrm{~K} \mathrm{~K}_{2} \mathrm{O} \cdot \mathrm{ha}^{-1}$. In all inoculated pots, one pre-germinated seed was soaked with $1 \mathrm{~mL}$ of bacterial suspension at sawing. The control treatments consisted of a positive control $\left(\mathrm{C}^{+}\right)$supplemented with soluble $\mathrm{KH}_{2} \mathrm{PO}_{4}$ at the concentration of $350 \mathrm{mgP} / \mathrm{g}$ soil, and a negative control $\left(\mathrm{C}^{-}\right)$supplemented with Moroccan rock phosphate, both without bacterial inoculation.

The experimental design is a completely randomized block system with 12 treatments, 1 host plant and 4 replications, resulting in a total of 48 experimental units.
Plant growth was followed during 6 weeks within which, each pot received $500 \mathrm{ml}$ water three times per week. Growth parameters (number of leaves, plant high, stem base diameter) were taken the third and the sixth week. At the end of the growth, plants were harvested, the aerial part separated from the root part, and then dried at $60{ }^{\circ} \mathrm{C}$ until the dry mass of materials became stable to determine shoot, root and total dry weight.

\subsection{Statistical Analysis}

Statistical analyses were performed with Sigma plot 12.0. The analysis of variance (ANOVA) was run to find difference between factors and the HSD Turkey test to compare the different treatments.

\section{Results}

\subsection{Strains Characterization on Plates Supplemented with Rock Phosphates of Different Origins}

\subsubsection{Solubilisation Index of Strains}

The efficacy of the different strains in solubilising sparingly soluble rock phosphates was first assessed on plates using solubilisation index (SI) an indicator for the strain efficiency, higher the SI, greater the solubilisation ability. Panthoea sp. and Bacillus sp. were able to solubilise the three rock phosphate types (SI $>1$ ), while Klebsiella sp. could only solubilised the Malian rock phosphates (Figure 1). Panthoea sp. with the solubilisation index of 3.65, 4.10 and 5.42 respectively for Malian, Moroccan and Mexican rock phosphates is the strain showing the greatest solubilisation index regarding the different rock phosphates. Significant differences can be clearly observed within Panthoea sp. and Bacillus sp. (2.93, 3.13 and 2.13 respectively) and within Bacillus sp. and Klebsiella sp. (1.81, 1 and 1 respectively). Regarding the activity of the different strains on plates, Panthoea sp. can be considered as the most efficient strains, followed by Bacillus sp. and Klebsiella sp. (Figure 2).

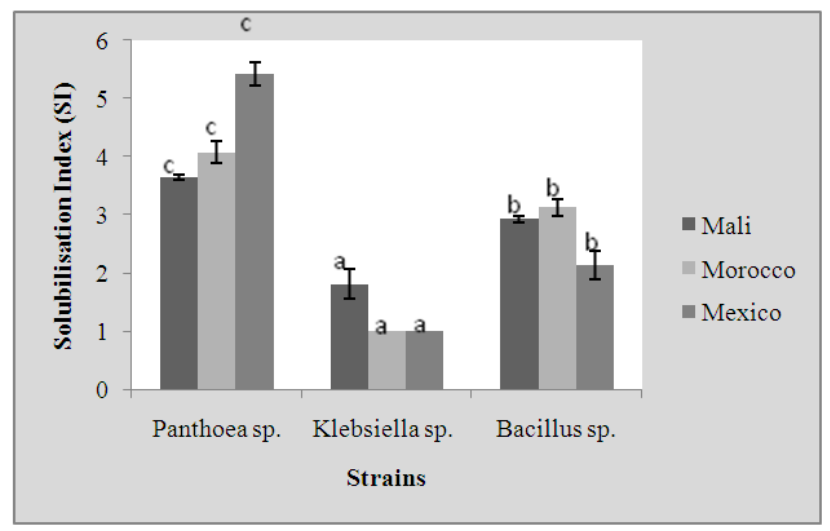

Figure 1. Solubilisation of different types of phosphate by each strain on plates. The different letters within the same phosphate type are significantly different $(p<0.05)$. 


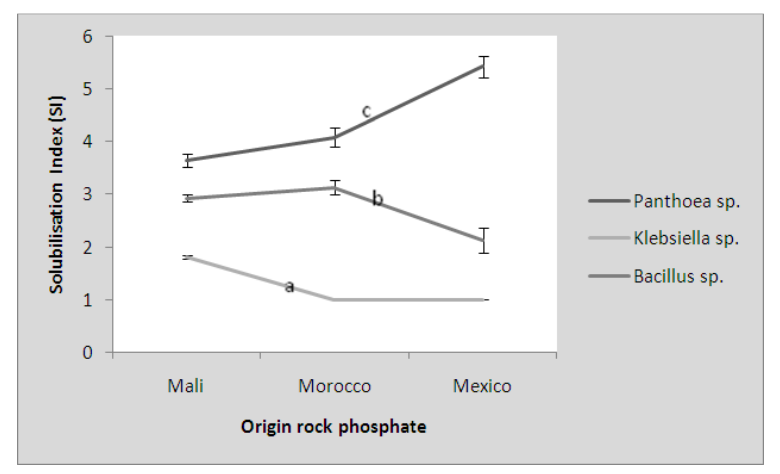

Figure 2. Relative efficiency of strains in solubilising rock phosphates of different origins on plates. The different letters indicate a significant difference $(p<0.05)$ between strains regardless the phosphate origin.

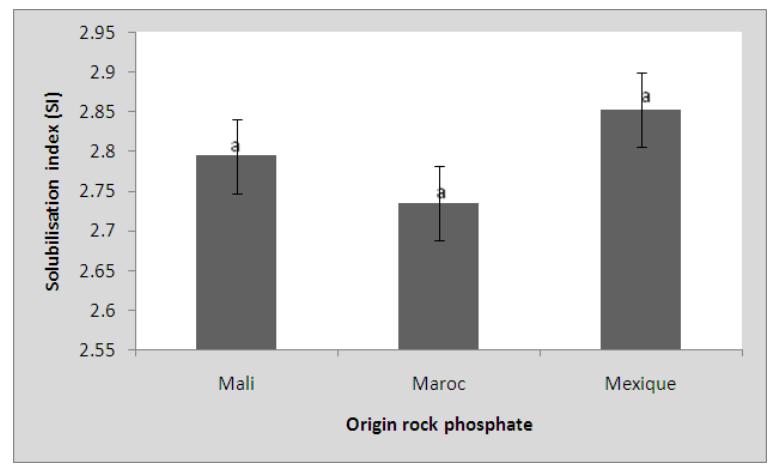

Figure 3. Fluency of the different rock phosphates to be solved by the strains on plates. The different letters indicate a significant difference between rock phosphates $(p<0.05)$.

\subsubsection{Fluency of the Different Rock Phosphate to be Solved on Plates}

There is no significant difference between the different rock phosphate solubilisation on plates (Figure 3). The different rock phosphates with an average solubilisation index of 2.794 (Mali), 2.734 (Morocco) and 2.852 (Mexico) show the same capacity to be solved.

\subsection{Strains Characterization in Liquid Cultures Supplemented with Rock Phosphates of Different Origins}

\subsubsection{Concentration of the Solved-P in Liquid Cultures and $\mathrm{pH}$ of the Corresponding Media}

In general, all the strains were able to mobilise phosphorus from insoluble sources, with significant difference within strains and control (Figure 4). Same like on plates, Panthoea sp. is the strain showing the highest efficiency in mobilising phosphorus from insoluble rock phosphates sources with an average amount of 1038.25, 996.67 and $1207.87 \mu \mathrm{gP} / \mathrm{g}$ for Malian, Moroccan and Mexican rock phosphates respectively. Contrary to the result obtained on plates, Klebsiella sp. appears much more efficient in liquid culture with average solved $\mathrm{P}$ of 862.57, 615.19 and $426.29 \mu \mathrm{gP} / \mathrm{g}$ respectively, compared to Bacillus sp. with average solved P of 810.86, 270.92 and $180.95 \mu \mathrm{gP} / \mathrm{g}$ respectively. Furthermore, Klebsiella sp. that was not able to show any visible activity on plates amended with Moroccan and Mexican rock phosphates could conversely mobilised significant amount in broth containing the same rock phosphate types. In general, the rock phosphate solubilisation is accompanied with drop of $\mathrm{pH}$ of the media, but no strong correlation could be established between the amount of the solved $\mathrm{P}$ and the $\mathrm{pH}$ of the corresponding media.

\subsubsection{Efficiency of Strains According to the Concentration of the Solved $P$}

There is a significant difference $(\mathrm{p}<0.05)$ between ability of strains in solubilising the different rock phosphates (Figure 5). Panthoea sp. presents the highest efficiency in solubilising all rock phosphates in liquid cultures followed by Klebsiella sp. and finally by Bacillus sp. Great differences can be easily observed within Panthoea sp. and Klebsiella sp. and within Klebsiella sp. and Bacillus sp.

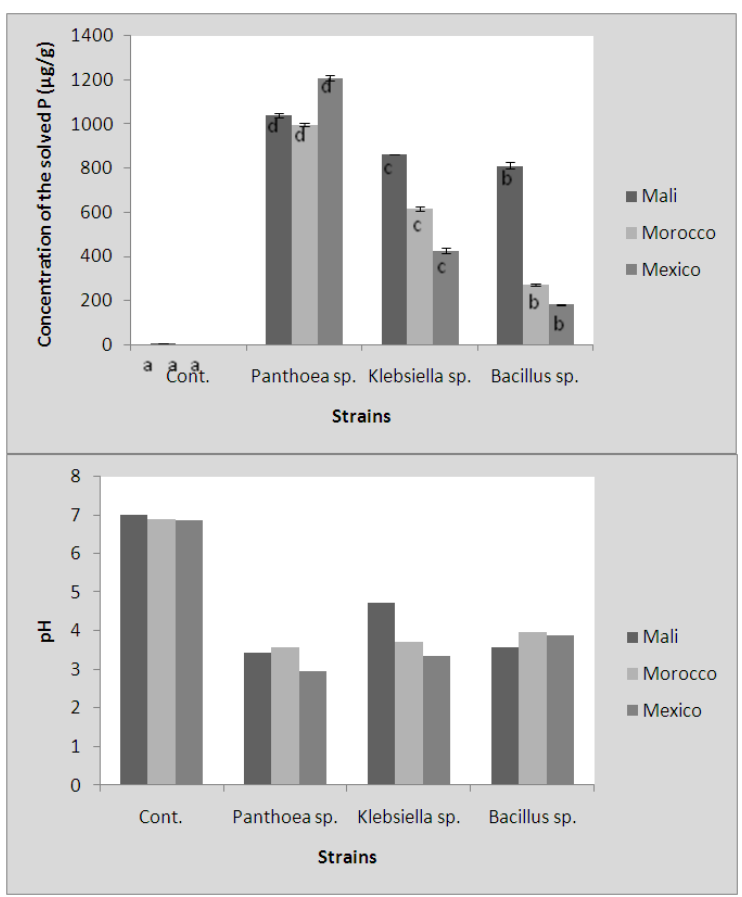

Figure 4. Concentration of the solved $P$ in liquid cultures amended with rock phosphates of different origins and the $\mathrm{pH}$ of the corresponding media. The different letters within the same phosphate type are significantly different $(p<0.05)$.

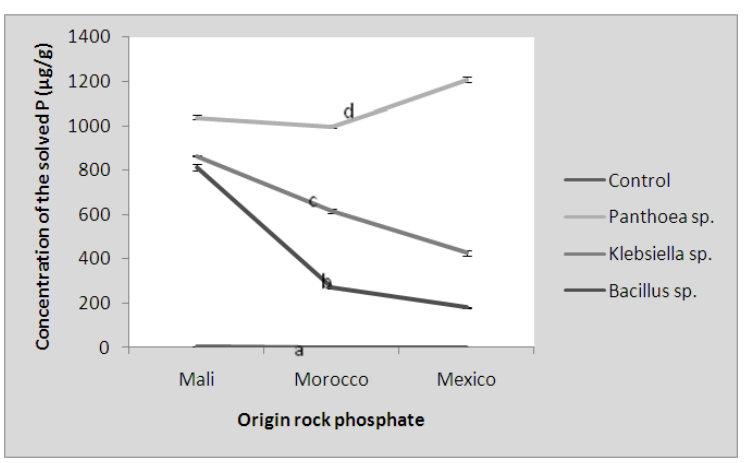

Figure 5. Aptitude of strains in solubilising rock phosphates of different origins in liquid media. The different letters indicate a significant difference between strains regardless the phosphate type $(p<0.05)$. 


\subsubsection{Fluency of the Different Rock Phosphate to be Solved in Liquid Media}

Contrary to the result obtained on plates with no significant difference on the ability of the different rock phosphates to be solved, there is a significant difference between the different rock phosphates in liquid cultures (Figure 6). The Malian rock phosphate $(679.59 \mu \mathrm{gP} / \mathrm{g})$ is the easiest phosphates to be solved by the different strains, followed by Moroccan (470.69 $\mu \mathrm{gP} / \mathrm{g}$ ) and Mexican rock phosphate $(453.79 \mu \mathrm{gP} / \mathrm{g})$.

\subsection{Effect of Inoculation by Strains on the Soybean Growth}

\subsubsection{Growth Parameters Three Weeks After Planting}

The number of leaves varies between 5 and 6 while the stem base diameter varies between 2.48 and $3.40 \mathrm{~cm}$ with no significant difference between treatments in both cases at three weeks after planting (Table 2). However, there is a significant difference $(\mathrm{p}<0.05)$ between treatments regarding the plant high. While the negative control (C-) shows the lowest score $(12.40 \mathrm{~cm})$, the best one is obtained with Bacillus sp. $(15.68 \mathrm{~cm})$ followed by Panthoea sp. $(15.00 \mathrm{~cm})$ and the consortium of the three strains $\mathrm{ABC}$ $(14.58 \mathrm{~cm})$. This shows the real aptitude of strains, either in single or in consortia to promote the plant growth regarding the plant high parameter.

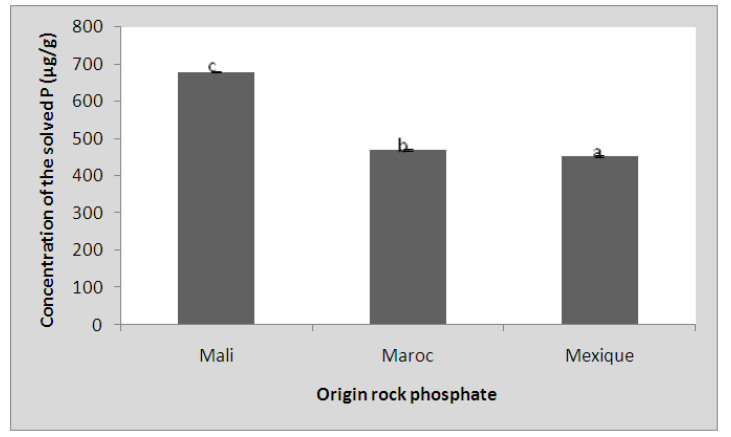

Figure 6. Facility of the different rock phosphates to be solved by the strains in liquid media. The different letters indicate a significant difference between rock phosphates $(p<0.05)$.

Table 2. Number of leaves, plant high and stem base diameter of soybean plants the third week after planting.

\begin{tabular}{|c|c|c|c|c|c|c|c|c|c|}
\hline Treatment & \multicolumn{2}{|c|}{$\begin{array}{l}\text { (a) Number of } \\
\text { leaves }\end{array}$} & \multicolumn{2}{|l|}{$\begin{array}{l}\text { Standard } \\
\text { deviation }\end{array}$} & \multicolumn{2}{|l|}{$\begin{array}{l}\text { (b) Plant high } \\
\text { (cm) }\end{array}$} & $\begin{array}{l}\text { Standard } \\
\text { deviation }\end{array}$ & $\begin{array}{l}\text { (c) Stem base } \\
\text { diameter }(\mathrm{cm})\end{array}$ & $\begin{array}{l}\text { Standard } \\
\text { deviation }\end{array}$ \\
\hline $\mathrm{C}-$ & $5 \mathrm{a}$ & & 0.50 & & $12.40 \mathrm{a}$ & & 0.43 & $2.70 \mathrm{a}$ & 0.48 \\
\hline $\mathrm{C}+$ & $6 \mathrm{a}$ & & 0.58 & & $13.78 \mathrm{bc}$ & & 0.33 & $3.40 \mathrm{a}$ & 0.43 \\
\hline A & $5 \mathrm{a}$ & & 0.00 & & $15.00 \mathrm{~cd}$ & & 0.71 & $2.78 \mathrm{a}$ & 0.39 \\
\hline B & $5 \mathrm{a}$ & & 0.00 & & $13.08 \mathrm{ab}$ & & 0.82 & $2.48 \mathrm{a}$ & 0.36 \\
\hline $\mathrm{C}$ & $5 \mathrm{a}$ & & 0.50 & & $15.68 \mathrm{~d}$ & & 0.40 & $3.27 \mathrm{a}$ & 0.21 \\
\hline $\mathrm{AC}$ & $5 \mathrm{a}$ & & 0.50 & & $14.08 \mathrm{bc}$ & & 0.15 & $2.75 \mathrm{a}$ & 0.35 \\
\hline $\mathrm{ABC}$ & $5 \mathrm{a}$ & & 0.50 & & $14.58 \mathrm{~cd}$ & & 0.66 & $2.63 \mathrm{a}$ & 0.21 \\
\hline \multicolumn{2}{|c|}{ (a) Source of Variation } & DF & & SS & & MS & & $\mathrm{F}$ & $\mathrm{P}$ \\
\hline \multicolumn{2}{|c|}{ Between Groups } & 6 & & 1.857 & & 0.310 & & 1.625 & 0.190 \\
\hline \multicolumn{2}{|l|}{ Residual } & 21 & & 4.000 & & 0.190 & & & \\
\hline \multicolumn{2}{|l|}{ Total } & 27 & & 5.857 & & & & & \\
\hline \multicolumn{2}{|c|}{ (b) Source of Variation } & DF & & SS & & MS & & $\mathrm{F}$ & $\mathrm{P}$ \\
\hline \multicolumn{2}{|c|}{ Between Groups } & 6 & & 30.244 & & 5.041 & & 16.970 & $<0.001$ \\
\hline \multicolumn{2}{|l|}{ Residual } & 21 & & 6.238 & & 0.297 & & & \\
\hline \multicolumn{2}{|l|}{ Total } & 27 & & 36.481 & & & & & \\
\hline \multicolumn{2}{|c|}{ (c) Source of Variation } & DF & & SS & & MS & & $\mathrm{F}$ & $\mathrm{P}$ \\
\hline \multicolumn{2}{|c|}{ Between Groups } & 6 & & 2.810 & & 0.468 & & 3.645 & 0.012 \\
\hline \multicolumn{2}{|l|}{ Residual } & 21 & & 2.698 & & 0.128 & & & \\
\hline \multicolumn{2}{|l|}{ Total } & 27 & & 5.508 & & & & & \\
\hline
\end{tabular}

The different letters within the same column indicate a significant difference $(\mathrm{p}<0.05)$ between treatments. A (Panthoea sp.), B (Klebsiella sp.), C (Bacillus sp.), AC (Panthoea sp. + Bacillus sp.), ABC (Panthoea sp. + Klebsiella sp. + Bacillus sp.).

\subsubsection{Growth Parameters Six Weeks After Planting}

Six weeks after planting, no real differences can be observed between treatments regarding the number of leaves. However, significant differences are noted between treatments as far as concern the plant high and the stem base diameter. Same like three weeks after planting, the best record is obtained with Bacillus sp. in both plant high (40.50 $\mathrm{cm})$ and stem base diameter $(4.93 \mathrm{~cm})$ among the inoculation treatments. In general, the stem base diameter varies with treatments, the highest performance obtained by the positive control $(5.20 \mathrm{~cm})$, followed by Bacillus sp., Panthoea sp. $(4.37 \mathrm{~cm})$ and the consortium (AC) of both Bacillus sp. and Panthoea sp. $(4.58 \mathrm{~cm})$. This shows the real aptitude of strains, either in single or in consortia to promote the plant 
growth regarding the different parameters.

Table 3. Number of leaves, plant high and stem base diameter of soybean plants six weeks after planting.

\begin{tabular}{|c|c|c|c|c|c|c|c|}
\hline Treatment & $\begin{array}{l}\text { (a) Number of } \\
\text { leaves }\end{array}$ & $\begin{array}{l}\text { Standard } \\
\text { deviation }\end{array}$ & $\begin{array}{l}\text { (b) Plant high } \\
\text { (cm) }\end{array}$ & $\begin{array}{l}\text { Standard } \\
\text { deviation }\end{array}$ & & $\begin{array}{l}\text { (c) Stem base } \\
\text { diameter (cm) }\end{array}$ & $\begin{array}{l}\text { Standard } \\
\text { deviation }\end{array}$ \\
\hline $\mathrm{C}-$ & $9 \mathrm{ab}$ & 0.50 & $32.33 \mathrm{a}$ & 3.09 & & $3.69 \mathrm{ab}$ & 0.21 \\
\hline $\mathrm{C}+$ & $10 \mathrm{ab}$ & 0.50 & $39.75 \mathrm{bc}$ & 2.75 & & $5.20 \mathrm{e}$ & 0.28 \\
\hline A & $10 \mathrm{ab}$ & 0.58 & $35.33 \mathrm{a}$ & 0.94 & & $4.37 \mathrm{~cd}$ & 0.45 \\
\hline B & $9 \mathrm{ab}$ & 0.50 & $34.93 \mathrm{a}$ & 0.90 & & $3.30 \mathrm{a}$ & 0.22 \\
\hline $\mathrm{C}$ & $10 \mathrm{ab}$ & 1.00 & $40.50 \mathrm{c}$ & 0.35 & & $4.93 \mathrm{~d}$ & 0.25 \\
\hline $\mathrm{AC}$ & $9 \mathrm{ab}$ & 0.50 & $36.21 \mathrm{ab}$ & 0.85 & & $4.58 \mathrm{~cd}$ & 0.19 \\
\hline $\mathrm{ABC}$ & $8 \mathrm{a}$ & 0.50 & $35.61 \mathrm{ab}$ & 1.76 & & $4.22 \mathrm{bc}$ & 0.14 \\
\hline (a) Source of Variation & $\mathrm{DF}$ & SS & MS & & $\mathrm{F}$ & & $\mathrm{P}$ \\
\hline Between Groups & 6 & 7.214 & 1.202 & & 3.258 & & 0.020 \\
\hline Residual & 21 & 7.750 & 0.369 & & & & \\
\hline Total & 27 & 14.964 & & & & & \\
\hline (b) Source of Variation & $\mathrm{DF}$ & SS & MS & & $\mathrm{F}$ & & $P$ \\
\hline Between Groups & 6 & 194.355 & 32.392 & & 9.960 & & $<0.001$ \\
\hline Residual & 21 & 68.299 & 3.252 & & & & \\
\hline Total & 27 & 262.653 & & & & & \\
\hline (c) Source of Variation & DF & SS & MS & & $\mathrm{F}$ & & $\mathrm{P}$ \\
\hline Between Groups & 6 & 10.658 & 1.776 & & 25.403 & & $<0.001$ \\
\hline Residual & 21 & 1.469 & 0.0699 & & & & \\
\hline Total & 27 & 12.127 & & & & & \\
\hline
\end{tabular}

The different letters within the same column indicate a significant difference $(\mathrm{p}<0.05)$ between treatments. A (Panthoea sp.), B (Klebsiella sp.), C (Bacillus sp.), AC (Panthoea sp. + Bacillus sp.), ABC (Panthoea sp. + Klebsiella sp. + Bacillus sp.)

\subsubsection{Root, Shoot and Total Plant Dry Weight Six Weeks After Planting}

Significant differences $(\mathrm{p}<0.05)$ are observed within strains regarding the root, shoot and total plant dry matter. Concerning the root dry mass, only one inoculated treatment Panthoea sp. (2.89 g) is significantly different from the negative control $\mathrm{C}$ - $(1.95 \mathrm{~g})$, but the best score is performed by the positive control C+ (3.92 g) supplied with soluble phosphate (Table 4). Regarding the root dry matter, all inoculated treatments are significantly different from the negative control. The best record is obtained by the consortium of the three strains ABC (2.75 g) followed by Bacillus sp. $(2.30 \mathrm{~g})$, Panthoea sp. $(2.24 \mathrm{~g})$ and then Klebsiella $\mathrm{sp} .(1.79 \mathrm{~g})$. As far as concern the total plant dry matter, the best record is still obtained with the positive control C+ $(6.21 \mathrm{~g})$. Among the inoculated treatments, Panthoea sp. $(5.14 \mathrm{~g})$ and the consortium of the three strains ABC (4.97 g) show the best performance, followed by Bacillus sp. (4.60 g) and Klebsiella sp. (4.00 g). This shows the real aptitude of strains, either in single or in consortia to promote the plant growth regarding the shoot, root and total plant dry masses.

Table 4. Shoot dry weight, root dry weight and total dry weight of soybean plants six weeks after planting.

\begin{tabular}{|c|c|c|c|c|c|c|}
\hline Treatment & $\begin{array}{l}\text { (a) Shoot dry } \\
\text { weight (g) }\end{array}$ & $\begin{array}{l}\text { Standard } \\
\text { deviation }\end{array}$ & $\begin{array}{l}\text { (b) Root dry } \\
\text { weight (g) }\end{array}$ & $\begin{array}{l}\text { Standard } \\
\text { deviation }\end{array}$ & $\begin{array}{l}\text { (c) Total plant } \\
\text { dry weight (g) }\end{array}$ & $\begin{array}{l}\text { Standard } \\
\text { deviation }\end{array}$ \\
\hline $\mathrm{C}-$ & $1.95 \mathrm{a}$ & 0.04 & $1.32 \mathrm{a}$ & 0.24 & $3.27 \mathrm{a}$ & 0.27 \\
\hline $\mathrm{C}+$ & $3.92 \mathrm{c}$ & 0.17 & $2.29 \mathrm{~cd}$ & 0.11 & $6.21 \mathrm{e}$ & 0.19 \\
\hline A & $2.89 \mathrm{~b}$ & 0.11 & $2.24 \mathrm{~cd}$ & 0.09 & $5.14 \mathrm{~d}$ & 0.04 \\
\hline B & $2.21 \mathrm{a}$ & 0.16 & $1.79 \mathrm{~b}$ & 0.12 & $4.00 \mathrm{bc}$ & 0.22 \\
\hline $\mathrm{C}$ & $2.30 \mathrm{a}$ & 0.18 & $2.30 \mathrm{~d}$ & 0.11 & $4.60 \mathrm{~cd}$ & 0.16 \\
\hline $\mathrm{AC}$ & $2.25 \mathrm{a}$ & 0.28 & $1.43 \mathrm{ab}$ & 0.25 & $3.69 \mathrm{ab}$ & 0.52 \\
\hline $\mathrm{ABC}$ & $2.23 \mathrm{a}$ & 0.19 & $2.75 \mathrm{e}$ & 0.21 & $4.97 \mathrm{~d}$ & 0.30 \\
\hline (a) Source of Variation & DF & SS & MS & & $\mathrm{F}$ & $\mathrm{P}$ \\
\hline Between Groups & 6 & 10.884 & 1.814 & & 60.890 & $<0.001$ \\
\hline Residual & 21 & 0.626 & 0.0298 & & & \\
\hline Total & 27 & 11.509 & & & & \\
\hline (b) Source of Variation & DF & SS & MS & & $\mathrm{F}$ & $\mathrm{P}$ \\
\hline Between Groups & 6 & 6.471 & 1.079 & & 36.136 & $<0.001$ \\
\hline Residual & 21 & 0.627 & 0.0298 & & & \\
\hline Total & 27 & 7.098 & & & & \\
\hline (c) Source of Variation & DF & SS & MS & & $\mathrm{F}$ & $P$ \\
\hline Between Groups & 6 & 23.857 & 3.976 & & 51.568 & $<0.001$ \\
\hline Residual & 21 & 1.619 & 0.0771 & & & \\
\hline Total & 27 & 25.476 & & & & \\
\hline
\end{tabular}


The different letters within the same column indicate a significant difference $(\mathrm{p}<0.05)$ between treatments. A (Panthoea sp.), B (Klebsiella sp.), C (Bacillus sp.), AC (Panthoea sp. + Bacillus sp.), ABC (Panthoea sp. + Klebsiella sp. + Bacillus sp.)

\subsubsection{Effect (\%) of the Different Treatments on Growth, Root, Shoot and Total Dry Weight of Soybean Six Weeks After Planting}

Based on the effect of inoculation on the different measured plant parameters compared to the negative treatment without inoculation, the different treatments can be classified as follow:

$\mathrm{C}+>\mathrm{A}=\mathrm{C}=\mathrm{ABC}>\mathrm{B}=\mathrm{AC}$. In general, Panthoea $\mathrm{sp}$. (35\%) and Bacillus sp. (34\%) better contribute to the soybean growth compare to non inoculated control supplied with non soluble Moroccan rock phosphate. The activity of Klebsiella sp. (13\%) that is low in general seems to be stimulated when associated with the two other strains $(33 \%)$.

Table 5. Effect (\%) of the treatments on growth, root, shoot and total dry weight of soybean plants six weeks after planting under pot grown conditions.

\begin{tabular}{llllllll}
\hline Treatment & $\begin{array}{l}\text { Number of } \\
\text { leaves }\end{array}$ & Plant height & $\begin{array}{l}\text { Stem base } \\
\text { diameter }\end{array}$ & $\begin{array}{l}\text { Root dry } \\
\text { weight }\end{array}$ & $\begin{array}{l}\text { Shoot dry } \\
\text { weight }\end{array}$ & $\begin{array}{l}\text { Total dry } \\
\text { weight }\end{array}$ & Average \\
\hline C + & 11 & 23 & 41 & 101 & 73 & 90 & 57 \\
A & 9 & 9 & 18 & 48 & 70 & 57 & 35 \\
B & 0 & 8 & 0 & 13 & 35 & 22 & 13 \\
C & 9 & 25 & 34 & 18 & 74 & 41 & 34 \\
AC & 0 & 12 & 24 & 15 & 9 & 13 & 12 \\
ABC & 0 & 10 & 14 & 14 & 108 & 52 & 33 \\
\hline
\end{tabular}

The effect $(\%)$ is calculated according to the formula: Effect $=\frac{(\mathrm{T}-\mathrm{C}-)}{\mathrm{C}-} \times 100$. Where, $\mathrm{T}$ is a given treatment and C- the negative control. A (Panthoea sp.), B (Klebsiella sp.), C (Bacillus sp.), AC (Panthoea sp. + Bacillus sp.), ABC (Panthoea sp. + Klebsiella sp. + Bacillus sp.)

\section{Discussion}

Several strains of bacterial and fungal species have been described and investigated in detail for their rock phosphate solubilising capabilities [21, 22]. Bacterial strains exhibiting $\mathrm{P}$ solubilising activity were detected on plates by the formation of halo/yellow zone around their colonies. This reaction is used to assess the $\mathrm{P}$ solubilisation activity of strains with the SI value as an indicator for the strain efficiency [23]. Although Klebsiella sp. did not showed any visible halo zone on plates amended with Moroccan and Mexican rock phosphates, it could conversely mobilized important amounts of phosphorus from these rock phosphate sources and could be considered as rock phosphate solubilisers. These contradictory results between plate halo detection and phosphate solubilisation in liquid cultures found earlier by Deubel and Merbach [24] and Fankem et al. [25] indicates that liquid culture should be associated to halo zone for rock phosphate solubilisers characterization. However, the plate method is still a feasible way to pre-screen the isolates that possess phosphate solubilising ability. While clear correlation was found between solubilisation ability on plate and in liquid culture with Panthoea sp., no correlation was observed with Klebsiella sp. and Bacillus sp. between solubilisation ability on plate and in liquid culture as mentioned in the previous investigations by Azziz et al. [26] and Fernández et al. [27]. Although all the strains showed good solubilisation in liquid cultures amended with the different rock phosphates, the amount of the solved $\mathrm{P}$ varied with the strain as well as the rock phosphate origin. Solubilisation of phosphate is commonly accompanied by a remarkable drop in $\mathrm{pH}[22,28,29]$, though no strong correlation was observed within the drop of $\mathrm{pH}$ and the amount of the solved P. Regarding the efficiency of strains on plates and in liquid cultures, Panthoea sp. shows the highest performance, followed by Bacillus sp. This performance was maintained on soybean growth regarding the different parameters measured, with a significant increase of $35 \%$ compared to the negative control. Although the activity of Klebsiella sp. (13\%) was not strong enough in this study, that strain altogether with Pseudomonas, Enterobacter and Microbacterium have been reported in several papers [30] as plant promoting strains. This value is therefore in agreement with Tandon [31] who reported that inoculation with phosphate solubilising microorganisms generally induces a growth increase of approximately $10-15 \%$. However, values greater than that range have been reported by Abou-el-Seoud and Abdel-Megeed [32] and Fankem et al. [33] who respectively found an increase of $26 \%$ and $36 \%$, with corn, and in this case $35 \%$ with soybean. Increasing the bioavailability of $\mathrm{P}$ in the soils with combined inoculation and rock materials has been reported by many researchers [34, 35, 36], which may lead to increased $\mathrm{P}$ uptake and plant growth [37, 38, 39]. In general, while Bacillus and Pseudomonas [40], Aspergillus and Penicillium [41] are considered as important genera of mineral phosphate solubilising bacteria and fungi respectively, only few reports indicated both Panthoea sp. and Klebsiella sp. as mineral phosphate solubilising bacteria and rare reports indicating their rock phosphate solubilising ability. The present study highlights the 
aptitude of Panthoea sp., Klebsiella sp. and Bacillus sp. in single or in consortia in solubilising rock phosphates of different origins as well their aptitude in promoting the soybean growth. This came to confirm the aptitude of those strains in solubilising sparingly soluble inorganic/organic phosphates including $\mathrm{Ca}_{3}\left(\mathrm{PO}_{4}\right)_{2}, \mathrm{AlPO}_{4}, \mathrm{FePO}_{4}$ and sodiumphytate, and would be recognized as inorganic/organic/rock phosphate solubilisers. Growth enhancement by bacteria may relate to their ability to produce extensive root length [42] and can also improve root development and increase the rate of water and mineral uptake $[43,44]$. This increase in growth may be attributed to auxin production [45], ACC-deaminase activity [46, 47] and production of organic acids [33] or phosphatases [48] to solubilise/mineralize $P$, thereby increasing phosphate nutrition of inoculated plants. Therefore, the positive effect on growth with non-soluble $\mathrm{P}$ may result from the synergic combination of both bacterial capacities for IAA production and $\mathrm{P}$ mobilisation. The use of phosphate-solubilising bacteria as inoculants simultaneously increase phosphorus uptake by the plant and crop yield [49]. Moreover, according to Amellal et al. [50] Panthoea agglomerans NAS206 can play an important role in the regulation of the water content (excess or deficit) of the rhizosphere of wheat by improving soil aggregation. This may hence justified its efficiency on the performed tests.

\section{Conclusion}

Natural rock phosphates have been recognised as a valuable alternative for $\mathrm{P}$ fertilisers, the modern agriculture being dependent on phosphorus derived from phosphate rock. However, the direct application of low-grade rock phosphate as a $\mathrm{P}$ source in soils is of little importance and need an addition of inoculums of phosphate solubilising microorganisms to improve the rock phosphate efficiency as a phosphorus source. The organisms possessing phosphate solubilising ability can convert the insoluble phosphatic compounds into soluble forms into soil and make it available to the crops. While Bacillus and Pseudomonas are generally considered as important genera of mineral phosphate solubilising bacteria, only few reports indicated both Panthoea sp. and Klebsiella sp. as mineral phosphate solubilising bacteria, and rare reports their rock phosphate solubilising ability. The present study highlights the aptitude of Panthoea sp., Klebsiella sp. and Bacillus sp. in solubilising rock phosphates of different origins as well their aptitude in promoting the soybean growth. These bacterial strains can be therefore recognized as inorganic/organic/rock phosphate solubilisers.

\section{Acknowledgments}

The authors would like to thank the Rothamsted International, African Fellow Programme, London, UK for providing the fund and the James Hutton Institute, Dundee, Scotland where part of this work was done.

\section{References}

[1] M.S. Khan, A. Zaidi, P.A. Wani, "Role of phosphate solubilising microorganisms in sustainable agriculture". In Sustainable Agriculture. E. Lictfouse et al. (Eds) Springer, 2009, p 552, DOI: 10.1007/978-90-481-2666-8_34.

[2] M.S. Khan, A. Zaidi, M. Ahemad, M. Oves, P.A. Wani, Plant growth promotion by phosphate solubilizing fungi - current perspective, vol. 56. Arch Agron Soil Sci., 2010, pp 73-98.

[3] A. Gaume, "Low P tolerance of various maize cultivars: the contribution of the root exudation". Ph.D. dissertation, Swiss Federal institute of Technology, Zurich, Switzerland, 2000 .

[4] A. Zaidi, M.S. Khan, M. Ahmad, M. Oves and P.A. Wani, "Recent advances in plant growth promotion by phosphate solubilizing microbes". In Microbial strategies for crop improvement. M.S. Khan, A. Zaidi and J. Mussarat (Eds.). Springer Verlag Berlin Heidelberg, 2009, pp. 23-132.

[5] W.I.A. Saber, K.M. Ghanem and M.S. EL-Hersh. Rock phosphate solubilisation by two isolates of Aspergillus niger and Penicillium sp. and their promotion to mung bean plants, vol. 4(7). Research Journal of Microbiology, 2009, pp. 235250 .

[6] M. Vassileva, N. Vassilev and R. Azcon, Rock phosphate solubilisation by Aspergillus niger on olive cake-based medium and its further application in a soil-plant system, vol. 14. World J. Microbio. Biotechnol., 1998, pp. 281-284.

[7] M.S. Reddy, S. Kumar, K. Babita and M.S. Reddy, Biosolubilisation of poorly soluble rock phosphates by Aspergillus tubingensis and Aspergillus niger, vol. 84. Bioresour. Technol., 2002, pp. 187-189.

[8] [8] C.C. Chuang, Y.L. Kuo, C.C. Chao and W.L. Chao, Solubilization of inorganic phosphates and plant growth promotion by Aspergillus niger, vol. 43. Biol. Fert. Soils, 2007, pp. 575-584.

[9] D. Cordell, J-O. Drangert, S. White, The story of phosphorus: Global food security and food for thought, vol. 19. Global Environmental Change, 2009, pp. 292-305.

[10] H.T. Rogers, R.W. Pearson, L.E. Ensminger, Comparative efficiency of various phosphate fertilizers, vol. 4. Agronomy, 1953, pp. 189-242.

[11] G.W. Cooke, The value of rock phosphate for direct application, vol. 24. Empire Journal of Experimental Agriculture, 1956, pp. 295-306.

[12] A.C. Gaur, \& K.P. Ostwall, Influence of phosphate dissolving bacilli on yield and phosphate uptake of wheat crop, vol. 10. Indian Journal of Experimental Biology, 1972, pp. 393-394.

[13] A.H. Babana, H. Antoun, Effect of Tilemsi phosphate rock solubilizing microorganisms on phosphorus-uptake and yield of field grown wheat in Mali, vol. 287. Plant and Soil, 2006, pp. 51-58.

[14] H. Hamdali, K. Moursalou, G. Tchangbedji, Y. Ouhdouch, H. Mohamed, Isolation and characterization of rock phosphate solubilizing actinobacteria from a Togolese phosphate mine, vol. 11(2). Afr. J. Biotechnol., 2012, pp. 312-320. 
[15] Y. Bashan, A.A. Kamnev, L.E. De Bashan, A proposal for isolating and testing phosphate-solubilizing bacteria that enhance plant growth, vol. 49. Biol Fertil Soils, 2013, pp. 1-2.

[16] M.M. Collavino, P.A. Sansberro, L.A. Mroginski, O.M. Aguilar, Comparison of in vitro solubilization activity of diverse phosphate-solubilizing bacteria native to acid soil and their ability to promote Phaseolus vulgaris growth, vol. 46. Biol Fertil Soils, 2010, pp. 727-738.

[17] C.S. Nautiyal, An efficient microbiological growth medium for screening phosphate solubilizing microorganisms, vol. 170. FEMS Microbiology Letters, 1999, pp. 265-270.

[18] R.S. Gadagi, \& T. Sa, New Isolation Method for Microorganisms Solubilizing Iron and Aluminium Phosphates Using Dyes, vol. 48(4). Soil Science and Plant Nutrition, 2002, pp. 615-618.

[19] M.A. Qureshi, Z.A. Ahmad, N. Akhtar, A. Iqbal, F. Mujeeb, M.A. Shakir, Role of phosphate solubilizing bacteria (PSB) in enhancing $\mathrm{P}$ availability and promoting cotton growth, vol. 22. The journal of animal \& plant sciences, 2012, pp. 204-210.

[20] J. Murphy, \& J.P. Riley, A modified single solution method for the determination of phosphate in natural waters, vol. 27. Analytica Chimica Acta, 1962, pp. 31-36.

[21] A.H. Babana, A.H. Dicko, K. Maïga \& D. Traoré, Characterization of rock phosphate-solubilizing microorganisms isolated from wheat (Triticum aestivum L.) rhizosphere in Mali, vol. 1(1). Journal of Microbiology and Microbial Research, 2013, pp. 1-6.

[22] H. Fankem, , L. Ngo Nkot, G. Nguesseu Njanjouo, G.V. Tchuisseu Tchakounte, A.V. Tchiazé Ifoué, D. Nwaga, Rock Phosphate Solubilisation by Strains of Penicillium spp. Isolated from Farm and Forest Soils of three Agro Ecological Zones of Cameroon, vol. 2(2). American Journal of Agriculture and Forestry, 2014, pp. 25-32.

[23] L.A. Fernandez, P. Zalba, M.A. Gomez, M.A. Sagardoy, Phosphate solubilization activity of bacterial strains in soil and their effect on soybean growth under greenhouse conditions, vol. 43. Biol. Fert. Soils., 2007, pp. 805-809.

[24] A. Deubel \& W. Merbach, "Influence of microorganisms on phosphorus bioavailability in soils". In Microorganisms in soils: roles in genesis and functions. F. Buscot \& A. Varma (Eds). Springer, Berlin Heidelberg, 2005, pp. 177-191.

[25] H. Fankem, M. Abba, L. Ngo Nkot, A. Deubel, W. Merbach, F-X. Etoa \& D. Nwaga, "Selecting indigenous P solubilizing bacteria for cowpea and millet improvement in nutrient deficient acidic soils of southern Cameroon". In Innovations for a green revolution in Africa: Exploring the Scientific Facts. A. Bationo, B. Waswa, J. Okeyo, F. Maina (Eds), Springer Science+Business Media B.V. 2011, pp. 391-398.

[26] G. Azziz, N. Bajsa, T. Haghjou, C. Taulé, Á. Valverde, J.M. Igual, A. Arias, Abundance, diversity and prospecting of culturable phosphate solubilizing bacteria on soils under crop-pasture rotations in a no-tillage regime in Uruguay, vol. 61. Appl. Soil Ecol., 2012, pp. 320-6.

[27] L. Fernández, B. Agaras, P. Zalba, L.G. Wall, C. Valverde, Pseudomonas spp. isolates with high phosphate-mobilizing potential and root colonization properties from agricultural bulk soils under no-till management, vol. 48(7). Biol. Fert. Soils, 2012, pp. 763-73.
[28] J. Kloeppe, R. Rodriguez-Kabana, A. Zehnder, J. Murphy, E. Sikora, C. Fernandez, Plant root-bacterial interactions in biological control of soil borne diseases and potential extension to systemic and foliar diseases, vol. 28(1). Australas Plant Pathol., 1999, pp. 21-6.

[29] N. Gupta, S. Jyotasanmayee, P. Reena and Dipikakerkatta, Solubilization of tricalcium phosphate and rock phosphate by microbes isolated from chromite, iron and manganese mines, vol. 66(2). Acta Bot. Croat., 2007, pp. 197-204.

[30] H. Rodriguez \& R. Fraga, Phosphate solubilizing bacteria and their role in plant growth promotion, vol. 17. Biotechnol. Adv., 1999, pp. 319-39.

[31] H.L. Tandon, "Phosphorus Research and Production in India". Fertilizer Development and Consultation Organisation New Delhi, 1987, p. 160.

[32] Abou-el-Seoud and A. Abdel-Megeed, Impact of rock materials and biofertilizations on $\mathrm{P}$ and $\mathrm{K}$ availability for maize (Zea Mays) under calcareous soil conditions, vol. 19. Saudi Journal of Biological Sciences, 2012, pp. 55-63.

[33] H. Fankem, L. Ngo Nkot, A. Deubel, J. Quinn, W. Merbach, F-X. Etoa and D. Nwaga, Solubilization of inorganic phosphates and plant growth promotion by strains of Pseudomonas fluorescens isolated from acidic soils of Cameroon, vol. 2. African Journal of Microbiology Research, 2008, pp. 171-178.

[34] Q.M. Lin, Z.H. Rao, Y.X. Sun, J. Yao, L.J. Xing, Identification and practical application of silicate-dissolving bacteria, vol. 1. Agric. Sci. China, 2002, pp. 81-85.

[35] H.S. Han \& K.D. Lee, Phosphate and potassium solubilizing bacteria effect on mineral uptake, soil availability and growth of eggplant, vol. 1(2). Res. J. Agric. Biol. Sci., 2005, pp. $176-180$.

[36] P. Marschner, "The role of rhizosphere microorganisms in relation to P uptake by plants". In The Ecophysiology of Plant-Phosphorus Interactions, Plant Ecophysio. Series. P.J. White \& J.P. Hammond (Eds). Springer, Heidelberg, 2009, pp. $165-176$.

[37] H.S. Han, E. Supanjani, K.D. Lee, Effect of co-inoculation with phosphate and potassium solubilizing bacteria on mineral uptake and growth of pepper and cucumber, vol. 52(3). Plant Soil Environ., 2006, pp. 130-136.

[38] M.A. Jorquera, M.T. Hernandez, Z. Rengel, P. Marschner, M.L. Mora, Isolation of culturable phosphobacteria with both phytate mineralization and phosphate-solubilization activity from the rhizosphere of plants grown in a volcanic soil, vol. 44. Biol. Fertil. Soils, 2008, pp. 1025-1034.

[39] S.J. Sabannavar \& H.C. Lakshman, Effect of rock phosphate solubilization using mycorrhizal fungi and phosphobacteria on two high yielding varieties of Sesamum indicum L., vol. 5(4). World J. Agric. Sci., 2009, pp. 470-479.

[40] P. Illmer, and F. Schinner, Solubilization of inorganic phosphates by microorganisms isolated from forest soil, vol. 24. Soil Biol Biochem., 1992, pp. 389-95.

[41] M.R. Motsara, P.B. Bhattacharyya, B. Srivastava, "Biofertilizers: their description and characteristics". In Biofertilizer Technology, Marketing and Usage. A Sourcebook-cum- Glossary, Fertilizer Development and Consultation Organisation, New Delhi, India, 1995, pp. 9-18. 
[42] X.F. Sheng \& W.Y. Huang, Physiological characteristics of strain NBT of silicate bacterium, vol. 38. Acta Pedol. Sin, 2001, pp. 569-574.

[43] M. Alexander, "Introduction to Soil Microbiology". Second ed. John Wiley \& Sons Inc., New York. 1997.

[44] K.M. Saghir, A. Zaidi, P.A. Wani, Role of phosphate solubilizing microorganisms in sustainable agriculture: a review, vol. 27. Agron. Sustain. Dev., 2007, pp. 29-43.

[45] P. Gyaneshwar, G. Naresh Kumar, L.J. Parekh, P.S. Poole, Role of soil microorganisms in improving $\mathrm{P}$ nutrition of plants, vol. 245. Plant and Soil, 2002, pp. 83-93.

[46] P.R. Naik, G. Raman, K.B. Narayanan \& N. Sakthivel, Assessment of genetic and functional diversity of phosphate solubilizing fluorescent pseudomonads strain from rhizospheric soil, vol. 8. BMC Microbiology, 2008, p. 230.
[47] M. Jayadi, B. Baharuddin \& Ibrahim, In vitro selection of rock phosphate solubility by microorganism from Ultisols in South Sulawesi, Indonesia, vol. 1(4). American Journal of Agriculture and Forestry, 2013, pp. 68-73.

[48] R. Chabot, H. Antoun, M.P. Cescas, Growth promotion of maize and lettuce by phosphate-solubilizing Rhizobium leguminosarum biovar phaseoli, vol. 184. Plant and Soil, 1996, pp. 311-321.

[49] S. Mehta \& S.C. Nautiyal, An efficient method for qualitative screening of phosphate solubilizing bacteria, vol. 43. Current Microbiol., 2001, pp. 51-56.

[50] N. Amellal, G. Burtin, F. Bartoli, and T. Heulin, Colonization of Wheat Roots by an Exopolysaccharideproducing Pantoea agglomerans strain and its effect on rhizosphere soil aggregation. Applied and Environmental Microbiology, 1998, pp. 3740-3747. 